\title{
Histomorphological changes, sperm quality and testosterone level after administration and cessation of Pegagan (Centella asiatica) extract in rats
}

\author{
N. Solihati ${ }^{1, *}$, B. Purwantara ${ }^{2}$, I. Supriatna ${ }^{2}$ and A. Winarto ${ }^{2}$ \\ ${ }^{1}$ Faculty of Animal Husbandry, Universitas Padjadjaran Bandung, \\ Jl. Raya Bandung-Sumedang KM 21, Jatinagor Sumedang, West Java - Indonesia \\ ${ }^{2}$ Faculty of Veterinary Medicine, Institut Pertanian Bogor, \\ Jl. Agatis, Dramaga Campus, Bogor 16680 - Indonesia \\ *Corresponding E-mail : nurcholidah@yahoo.com
}

Received September 23, 2018; Accepted February 05, 2018

\begin{abstract}
ABSTRAK
Tujuan penelitian ini untuk mengetahui perubahan histomorfologi tubulus seminiferi testis, kualitas sperma dan kadar testosteron setelah pemberian dan penghentian ekstrak pegagan. Penelitian menggunakan rancangan acak lengkap faktorial $4 \times 2$, faktor pertama adalah dosis-lama pemberian, faktor kedua adalah lama penghentian ekstrak pegagan. Parameter terdiri dari tingkat spermatogenesis, kualitas sperma (motilitas, konsentrasi dan abnormalitas), dan kadar testosteron. Data diolah menggunakan analisis ragam dan uji Duncan. Hasil penelitian menunjukkan bahwa tidak terdapat interaksi antara perlakuan dosis-lama pemberian dengan perlakuan lama penghentian ekstrak pegagan. Tidak terdapat perbedaan yang nyata dari perlakuan dosis-lama pemberian ekstrak pegagan terhadap derajat spermatogenesis, motilitas sperma dan level testosteron. Perlakuan lama penghentian ekstrak pegagan tidak berpengaruh nyata terhadap derajat spermatogenesis, motilitas sperma, dan level testosterone namun hasil penelitian ini memberikan indikasi bahwa penghentian ekstrak pegagan selama 12 hari meningkatkan derajat spermatogenesis dan motilitas sperma, hal ini menunjukkan adanya potensi antifertilitas ekstrak pegagan. Disimpulkan bahwa ekstrak pegagan memiliki potensi sebagai agen antifertilitas namun tingkat spermatogenesis, kualitas sperma dan kadar testosteron masih dalam kisaran normal untuk proses reproduksi dan tidak irreversible, dan pegagan dapat dieksplorasi sebagai agen antifertilitas reversibel.
\end{abstract}

Kata kunci : perubahan histomorfologi, ekstrak pegagan, kualitas semen, testosteron

\begin{abstract}
The objective of this study was to determine histomorphological change of seminiferous tubules, sperm quality and testosterone level after administration and cessation of pegagan extract. The research used $4 \times 2$ factorial complete randomized design, the first factor was dose-administration duration and the second factor was cessation length of pegagan extract. Parameters consisted of degree of spermatogenesis, sperm quality (motility, concentration and abnormality), and testosterone level. The data were processed using analysis of variance and Duncan's test. Results showed that there was no interaction between dose-administration duration and cessation length. There was no significant difference of dose-administration duration of pegagan on degrees of spermatogenesis, sperm motility and testosterone level. Cessation length did not significantly affect degrees of spermatogenesis, sperm
\end{abstract}


motility, and testosterone level although these results indicated that cessation of pegagan extract for 12 days increased degrees of spermatogenesis and sperm motility, indicated the antifertility potency of pegagan extract. In conclusion, Pegagan extract has potency as anti-fertility agent although the degree of spermatogenesis, sperm quality and testosterone levels were still in the normal range for the reproductive process and not irreversible, and pegagan could be explored as an reversible anti-fertility agent.

Keywords: histomorphological change, pegagan extract, sperm quality, testosterone

\section{INTRODUCTION}

Activity of male primary reproductive organ related to spermatogenesis and androgenesis happens in the testis. Spermatogenesis is a process of sperm formation in the seminiferous tubules of testis which involves spermatogenic cells (the spermatogonia, spermatocytes and spermatids). Furthermore, spermatids transformed into sperm which is then stored in the cauda epididymis before being ejaculated. Androgenesis is a process of androgen formation such as testosterone that is required for spermatogenesis. Development of spermatogenic cells in the seminiferous tubules, quality of sperm and testosterone level are parameter in analyzing the activity of anti-fertility agent in male.

Pegagan (Centella asiatica) is a medicinal plant that has been used extensively to treat various diseases. Pegagan has been reported to contain a variety of compounds such as triterpenoids, essential oils, flavonoids, polysaccharides, polyyne-alkene, amino acids, fatty acids, sesquiterpenes, alkaloids, sterols, carotenoids, tannins, chlorophyll, pectin, inorganic salts, etc. (Zheng and Qin, 2007). Triterpen, flavonoid and alkaloid were considerate as spermicidal agents in humans whereas tannins had effect involving in semen coagulation; flavonoid glycoside has antihyaluronidase activity (Farnsworth and Waller, 1982). Qualitative analysis of pegagan extract was conducted in 2011 in Research Laboratory of Research Centers of Medicinal Plants and Spices (BALITRO) showed that pegagan contains some compounds such glycosides $(++++)$, saponins $(+++)$, tannins $(+++)$, triterpenoids $(+++)$, and alkaloids $(++)$.

Some researchers reported that pegagan has anti-spermatogenic effect and anti-fertility activity in male rats (Noor and Ali, 2004), degeneration of sperm, decreased of sperm counts and motile sperm in mice (Heidari et al., 2007), some degeneration of spermatogenic cells and decrease spermatozoa in lumen seminiferous tubules (Yunianto et al., 2010). In the previous result
(Solihati et al., 2013), it was found that pegagan extract dose up to $450 \mathrm{mg} / \mathrm{kg}$ body weight and administration duration up to 49 days did not cause infertility in male rats, but there were indications leading to infertility such as a decline in populations of spermatogenic cells and quality sperm, although still within normal range. In addition, it was also indicated that pegagan extract administration for 28 days was considered more efficient than longer administration duration to decrease sperm quality and population of spermatogenic cells. Therefore, combination of lower administration duration and higher dose of pegagan extract should be performed to find out the anti-fertility effect of pegagan.

One factor leading to unpopularity of male contraceptive is the concern about the drug effects, such as irreversibility and low libido. Therefore, it is necessary to study the anti-fertility effect of pegagan and the reversibility by conducting treatment of cessation length after pegagan extract administration. The purpose of this study was to determine histomorphological changes in the seminiferous tubules of testes, to evaluate sperm quality and testosterone levels after administration and cessation of pegagan extract.

\section{MATERIALS AND METHODS}

Twenty four rats rats (Rattus norvegicus), strain of Sprague Dawley, at 16 weeks old, and body weight in range of $240-303 \mathrm{~g}$ were used in this research. The rats were obtained from animal laboratory of Indonesia Ministry of Health. The rats were placed in a rectangular cage $(41 \mathrm{~cm} \times 31$ $\mathrm{cm} \times 20 \mathrm{~cm}$ ), and were adapted for two weeks. All treated rats were given the same feed $(18 \%$ protein, $5 \%$ fat, $8 \%$ fiber, $13 \%$ ash, $12 \%$ moisture content) and drinking water ad libitum. Necessary ingredients in the study were pegagan that was extracted in the test laboratory of Research Centers of Medicinal Plants and Spices (BALITRO). Other materials used were anesthetics, Buffer Normal Formalin (BNF) 10\%, 
materials for evaluating sperm quality, histomorphology, and hormone analysis. The tools used in this research were animal cages, analytical balance, stomach probes, fixtures evaluation of sperm quality, Neubauer chamber, surgical instruments, microtomes, microscopes and hormonal analytical equipment.

\section{Experimental Design}

This study was conducted with a complete randomized design (CRD), factorial pattern. The first factor was combination of dose (450 and 600 $\mathrm{mg} / \mathrm{kg}$ ) and administration duration (21 and 28 days). In the previous result (Solihati et al., 2013), dose of pegagan extract up to $450 \mathrm{mg} / \mathrm{kg}$ body weight did not cause infertility in male rats and pegagan extract administration for 28 days was considered more efficient than longer administration duration, therefore we would like to try higher dose $(600 \mathrm{mg} / \mathrm{kg}$ body weight $)$ and the shorter duration (21 days). The second factor was cessation length of pegagan extract ( 1 and 12 days). The effect of cessation on spermatogenesis process was in 12 days. There were 8 treatments combinations: 1) $450 \mathrm{mg}-21$ days-1 day; 2) 450 mg-21 days-12 days; 3) 600 mg-21 days-1 day; 4) $600 \mathrm{mg}-21$ day-12 days; 5) $450 \mathrm{mg}-28$ days-1 day; 6) $450 \mathrm{mg}-28$ day-12 days; 7) $600 \mathrm{mg}-28$ day-1 day; and 8) $600 \mathrm{mg}-28$ day-12 days (Table 1).

The rats were divided randomly and allocated to the 8 treatments with 3 rats per treatment as replications, so a total of 24 rats were used for all treatments. Rats were placed in cages $(41 \mathrm{~cm} \times 31 \mathrm{~cm} \times 20 \mathrm{~cm})$ and adapted for two weeks. Rations containing $18 \%$ protein, $5 \%$ fat, $5 \%$ fiber, $8 \%$ ash and drink water were given ad libitum. The previous study (Solihati et al., 2013) showed that pegagan extract dose of $450 \mathrm{mg} / \mathrm{kg}$ resulted in decrease of late spermatid, motility, concentration dan testosterone level, but tstill maintaining sperm quality dan spermatogenic cells population. Based on these results, higher dose of pegagan extract was implemented in this study, i.e. $600 \mathrm{mg} / \mathrm{kg}$ to know further effect on sperm fertility. The previous study also showed that administration duration of pegagan extract for 28 days had no significant effect. Therefore, in this study shorter administration duration was implemented, i.e. 21 days.

\section{Treatments}

Each treatment consisted of 3 rats that previously had been randomly divided, each rat was numbered in its tail. Viscous extract of pegagan was weighted according to dose, then dissolved in aquabides. Pegagan extract was gived to all rats treatment. The administration of pegagan extract was carefully carried out to each rat using a sonde every morning between of 06.00 to $8.00 \mathrm{am}$. These treatments were conducted in accordance to animal welfare regulations from Animal Care and Use Committee, Institut Pertanian Bogor.

\section{Parameters}

Parameters measured were histological changes in the testis seminiferous tubules, sperm quality (motility, concentration and abnormal sperm) and testosterone levels.

\section{Procedure of Extraction}

Pegagan plant extraction was carried out in the laboratory of Balai Penelitian Tanaman Obat dan Rempah (BALITRO) with the following procedures: pegagan leaves and stems were collected, washed and air dried at room temperature to dry (until the leaves were dry $/ 0 \%$ water compound inside) for about five days. The air dried materials were then ground with a grinding machine. The resulted powder was weighed. Then, the pegagan powder was put in a

Table 1. Treatment Combinations Used

\begin{tabular}{ccc}
\hline $\begin{array}{c}\text { Combination of Dose } \\
\text {-administration Duration of } \\
\text { Pegagan Extract }\end{array}$ & \multicolumn{2}{c}{ Cessation Length of Pegagan Extract for } \\
\cline { 2 - 3 } $450 \mathrm{mg}-21$ days & $450 \mathrm{mg}-21$ days-1 day & 12 days \\
$600 \mathrm{mg}-21$ days & $600 \mathrm{mg}-21$ days-1 day & $600 \mathrm{mg}-21$ days-12 days \\
$450 \mathrm{mg}-28$ days & $450 \mathrm{mg}-28$ days-1 day & $450 \mathrm{mg}-28$ days-12 days \\
$600 \mathrm{mg}-28$ days & $600 \mathrm{mg}-28$ days-1 day & $600 \mathrm{mg}-28$ days-12 days \\
\hline
\end{tabular}


steel pan and was diluted in $70 \%$ solvent ethanol with ratio of 1: 5 (pegagan powder: solvent), so that the pegagan powder submerged and was easily shaken. The mixture was then mechanically stirred for three hours and then the mixture was left in room temperature overnight. The mixture was then filtered using Whatman paper filter (pore size $10 \mathrm{~m}$ ) to obtain the filtrate, then was concentrated using a rotary evaporator until the solvent evaporates, and thus, a thick pegagan extract was eventually obtained.

\section{Procedure of Animal Treatment}

At the end of each treatment, rats were anaesthetized intraperitoneally with ketamine dose of $10 \mathrm{mg} / 100 \mathrm{~g}$ body weight. Rat blood sampling was performed using $3 \mathrm{cc}$ syringe for making serum.

The rat's testicles were taken for testicular histological preparations. The rat's epididymal sperm was taken to be evaluated.

\section{Procedure of Histomorphological Evaluation of Seminiferous Tubules}

Rat's testicles obtained at the time of sampling were then put into a $10 \%$ Buffer Normal Formalin (BNF) solution, were fixed for at least one week, and were trimmed, dehydrated, cleared and embedded in histological wax to become testicle histological preparates. The preparates were then cut into preparate stripes using a rotary microtome. The preparate stripes were then stained with haematoxylin and eosin prior to microscopic observation to look for changes in the histomorphology of seminiferous tubules.

\section{Evaluation on the Degree of Spermatogenesis}

Analysis of seminiferous tubules histomorphology was done by determining the degree of spermatogenesis. Evaluation was conducted with the histomorphological staining approach using haematoxylin eosin (HE) (Kiernan, 1990). Distribution of the degree of spermatogenesis observed included spermatogonia, spermatocytes, spermatids, and spermatozoa in the lumen of the seminiferous tubules. Observations of degree of spermatogenesis was observed from 25 seminiferous tubules, replicated for each treatment with consistent observation position i.e. top, middle, bottom, left and right, respectively of 5 overpass of view. Preparations readout method used was in accordance with the criteria of Johnsen (Syahrum 1997). The criteria were as follows:

10 : Spermatogenesis fully and regularly, many spermatozoa accumulate in the middle of the lumen, normal seminiferous epithelium

9 Sperm to clump together in the middle of a lot of lumens, it appears most of the seminiferous epithelium off (sloughing)

8 : Epithelium seminiferous regular and complete, but the number of spermatozoa in the tubules less than 10 cells

7 : No spermatozoa in the seminiferous tubules, but many number of spermatids was found

6 : No spermatozoa in the seminiferous tubules and spermatids number less than 10 cells

5 : No spermatozoa and spermatids in the seminiferous tubules, but many spermatocytes

4 : No spermatozoa in the seminiferous tubules and the number of spermatocyt less than five cells

3 : Germinal cells in the seminiferous tubules is only comprised of spermatogonial

2 : In the seminiferous tubules contained no germ cell Sertoli cell only

1 : In the seminiferous tubules contained no cells

\section{Evaluation of Sperm Quality}

Sperm samples were taken from the cauda epididymis by slicing and pressing the cauda epididymis to force the sperm out. The sperm was placed in glass objects for further evaluation of motility, concentration and sperm abnormalities.

\section{Sperm Motility}

Observation of sperm motility was made by mixing one drop of semen from the cauda epididymis with two drops of physiological saline in the glass object, then the mixture was covered with a cover glass for further observation under a microscope with 10 times magnification. Spermatozoa which actively moved forward was compared to non-moving or moving in place, and expressed as a percentage. Motility observations made from five field perspective. 
Sperm Concentration. The concentration of spermatozoa was calculated with a Neubauer chamber as follows: $1 \mu \mathrm{L}$ semen was taken from the cauda epididymis with a micropipette and mixed with $499 \mu \mathrm{L}$ formolsalin in the mini tube, so that the dilution ratio was 1:500. The mixture was homogenized and then was dropped into the Neubauer chamber to be calculated under a microscope with 40 times magnification. The calculation was performed on five of the 25 rooms available with a diagonal direction (upper and lower right corner, left corner of the top and bottom, and middle). Numbers of spermatozoa obtained from the sum of five rooms were then multiplied by $25 \times 10^{6}$ cells $/ \mathrm{mL}$.

Sperm Abnormality. Observation of sperm abnormality was done by taking a drop of semen from the cauda epididymis which was then put in a glass object. The semen sample was then evenly stirred with three drops of eosin negrosin. Furthermore, the shape of sperm was observed by making sperm preparation on the other glass object. The sperm sample was allowed to dry and observed under a microscope with 10 times magnification. Calculation performed on abnormal shaped sperm spermatozoa with coiled tail and head end, and then compared with the number of spermatozoa present in the field of view and expressed in percent.

\section{Hormonal Analysis}

Hormonal analysis was started by taking blood from the rat's heart at the end of the study. Specimens to be used in this study were rat blood serum. Hormonal analysis was performed using the ELISA (enzyme-linked immunosorbent assay) method. Work procedures were as follows: A total of $20 \mu \mathrm{L}$ for each standard, control, and sample wells were prepared in exact amount using different tips for each well. A total of $200 \mu \mathrm{L}$ conjugating enzyme was put into each well and evenly mixed for 10 seconds. The mixture was then incubated for 60 minutes at room temperature without any cover. The incubation of sample and conjugating enzyme was done to bind each other. The wells were then rinsed 3 times with wash solution (400 $\mu \mathrm{L} /$ well $)$ and were immediately dried by positioning each well upside down. After that, $100 \mu \mathrm{L}$ substrate or chromogen solution was added to each well. The wells were then stored in a light-free room because the substrate is susceptible to light. The wells were then incubated for 15 minutes at room temperature. The enzymatic reaction was stopped by adding $100 \mu \mathrm{L}$ stop solution $\left(\mathrm{H}_{2} \mathrm{SO}_{4}\right)$. The sample from each well was then read in ELISA reader at a wavelength of $450 \mathrm{~nm}$ for 10 minutes after the addition of stop solution.

\section{Data Analysis}

The data were analyzed using analysis of variance (ANOVA), and the differences between treatments were analyzed using Duncan test.

\section{RESULTS AND DISCUSSION}

\section{The Change of Seminiferous Tubules}

a. Histomorphological of Seminiferous Tubules

Testicular seminiferous tubule consists of various spermatogenic cell types (spermatogonia, primary spermatocytes, secondary spermatocytes, early spermatids, late spermatids), sperm and Sertoli cells. Among seminiferous tubules were interstitial cells or Leydig cells (Figure 1).

\section{b. Degree of Spermatogenesis}

Degree of spermatogenesis is a value that expresses the level of spermatogenesis development in the seminiferous tubules based on the presence and extent of spermatogenic cells. Assessment on the degrees of spermatogenesis is expressed with numbers (1-10). Criteria of the spermatogenesis degree are shown in Figure 2. These figures were derived from results of this study.

Means of the degrees of spermatogenesis observed in this study are shown in Table 2. Table 2 showed that means of the degrees of spermatogenesis ranged from 6.31 up to 9.75 . Results showed that 12 days cessation of pegagan extract increased the degree of spermatogenesis except in $450 \mathrm{mg} / \mathrm{kg} \mathrm{BW}$ for 28 days treatment. Results of ANOVA showed that there was no interaction between treatments of dose-duration with cessation length. Also, treatment of doseduration did not significantly affect the degrees of spermatogenesis. Similarly, treatment of cessation length did not significantly affect the degrees of spermatogenesis although there was increase after 12 days cessation of pegagan extract except in $450 \mathrm{mg} / \mathrm{kg} \mathrm{BW}$ for 28 days treatment.

These results indicated that the histomorphological changes of the seminiferous tubules were in the range of middle to high. Rats with high degree of spermatogenesis $(>8)$ maintained spermatogenesis and produced spermatogenic cells and sperm that is needed for 


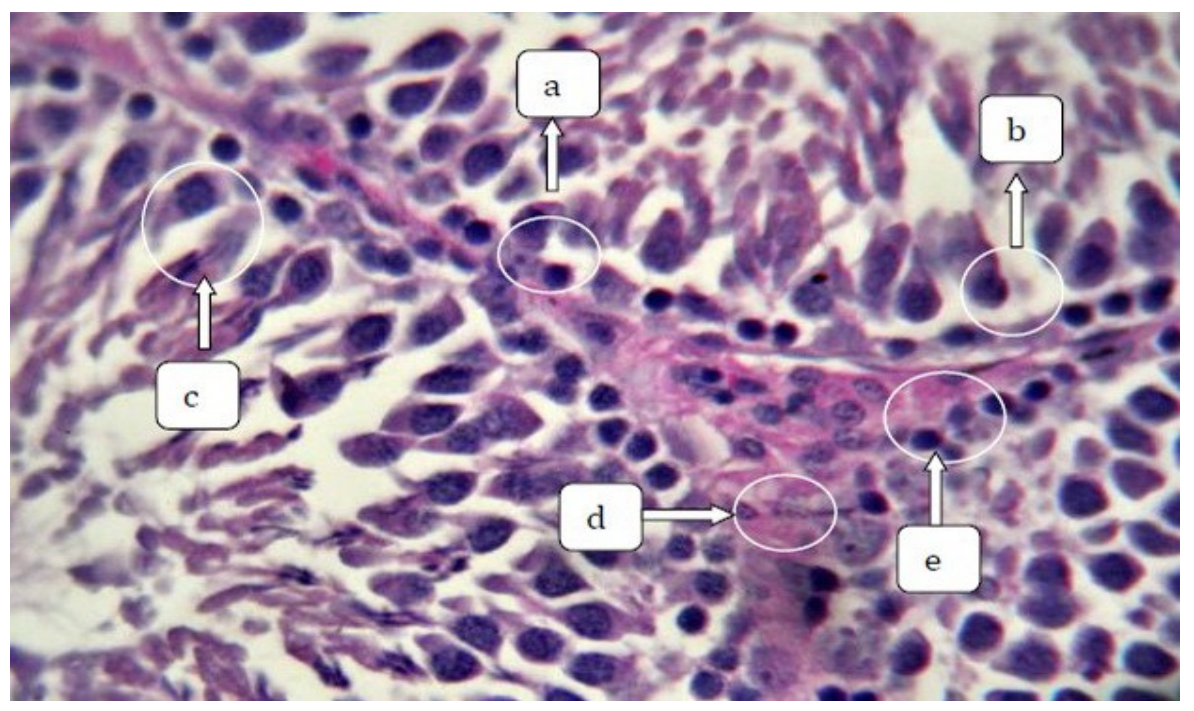

Figure 1. Seminiferous tubules cross-sectional. a: spermatogonia, b: primary spermatosit, c: late spermatid, d: Sertoli cell, e: Leydig cell. (Haematoxylin and eosin staining, x100)

further reproduction process. In contrast, rats with low degree of spermatogenesis indicated inhibition of spermatogenesis with severe degenerative changes in some seminiferous tubules. These results suggested that the pegagan extract caused degenerative changes in the testicles, but the response perhaps was influenced by individual factors.

Results of this study showed that 12 days cessation of pegagan increased the degree of spermatogenesis except in the $450 \mathrm{mg} / \mathrm{kg} \mathrm{BW}$ for 28 days treatment. Cessation of pegagan extract for 12 days resulted lower degree of spermatogenesis than 1 day cessation. This study showed that the damage occurred in the seminiferous tubules was the degradation of spermatogenic and Sertoli cells, so there was not enough cells in seminiferos tubules required for spermatogenesis (Figure 2F upper arrow). Degradation of the seminiferous tubules due to pegagan extract administration for 28 days could not be recovered even after 12 days of cessation because the degradation caused the loss of all cells in the seminiferous tubules. Degradation of seminiferous tubules in this study varied in individual rat, ranging from $4 \%$ to $60 \%$. It showed the individual factors contributed to the response after the pegagan extract administration.

High degree of spermatogenesis $(<8)$ indicated that the resulting sperm were still few and allegedly affected sperm quality, especially sperm concentration and motility. Furthermore, high degree of spermatogenesis would affect the success of the matting ability and pregnancy. The cessation of pegagan extract for 12 days caused higher degree of spermatogenesis than that for 1 day cessation. This indicated that there had been a recovery of seminiferous tubules condition. This might happen if the degradation that occurred in the seminiferous tubules did not cause total destruction of the cells in the seminiferous tubules.

Heidari et al. (2012) reported that oral administration of pegagan cause reproductive toxicity in male rats. Incidence of toxicity includes degenerative changes in the seminiferous tubules, the absence of sperm in the testis and apoptosis of germ cells, likely through direct destruction of the testis without severe damage to the endocrine function of the testicles.

Seminiferous tubules damage is indication of male reproductive risk. Based on the experimental results, Heidari et al. (2012) suggested gonadotoxic potential of pegagan. One of the reasons for this effect could be pegagan interaction with optimum energy metabolism for sperm vitality and motility. It was also reported that pegagan can result in apoptosis in male rat germ cells. These results indicated that pegagan, similar to other medicinal plants, may directly interfere in the spermatogenesis process. The increase of apoptosis germ cell was possibly due to increased peroxide radical generation in the testis following pegagan treatment. Therefore, pegagan could also induce apoptotic pathways through activation of caspases. The results 

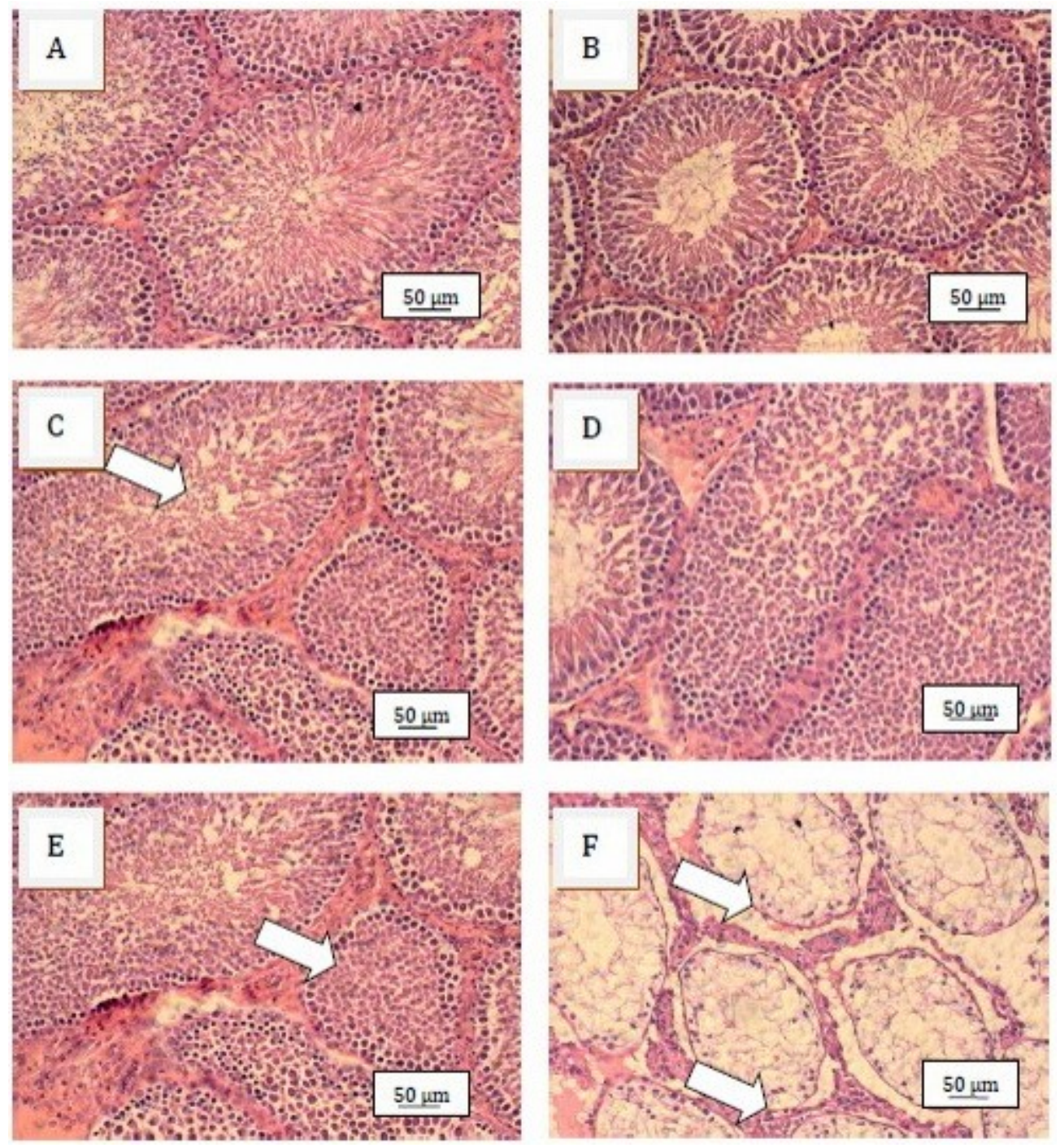

Figure 2. Seminiferous tubules cross-section, showing the degrees of spermatogenesis. A: value of 10; B: value of 9; C (arrow): value of 8; D: value of 7; E (arrow): value of 5; F: value of 1 . Haematoxylin and eosin staining, $\mathrm{Bar}=50 \mu \mathrm{m}$.

Table 2. Means of Spermatogenesis Degrees of Rats after Pegagan Extract Administration and Cessation of Pegagan Extract

\begin{tabular}{cccc}
\hline $\begin{array}{c}\text { Treatment of Dose- } \\
\text { administration Duration of } \\
\text { Pegagan Extract }\end{array}$ & \multicolumn{2}{c}{$\begin{array}{c}\text { Means of Spermatogenesis Degrees after } \\
\text { Cessation of Pegagan Extract for }\end{array}$} & Means \\
\cline { 2 - 3 } & 1 day & 12 days & \\
\hline $450 \mathrm{mg}-21$ days & $8.40 \pm 1.87$ & $9.75 \pm 0.17$ & $9.07 \pm 1.40$ \\
$600 \mathrm{mg}-21$ days & $7.75 \pm 0.23$ & $7.80 \pm 0.88$ & $7.77 \pm 0.58$ \\
$450 \mathrm{mg}-28$ days & $7.72 \pm 2.77$ & $6.31 \pm 2.04$ & $7.01 \pm 2.31$ \\
$600 \mathrm{mg}-28$ days & $6.43 \pm 0.26$ & $8.75 \pm 0.08$ & $7.59 \pm 1.28$ \\
Means & $7.57 \pm 1.60$ & $8.15 \pm 1.63$ & \\
\hline
\end{tabular}


indicated that pegagan has some effects in the male rat reproductive system. Furthermore, pegagan can cause changes in the structure of the testicular histology, characterized by edema and reduced spermatogenesis. Result of our research also show that pegagan interfere the spermatogenesis process as showed by increase of spermatogenesis degrees after cessation of pegagan administration. The decrease of spermatogenesis degrees after treatment of pegagan extract may be due to active compound of pegagan that affect apoptosis and degenerative changes in seminiferous tubules such as triterpen, flavonoid and alkaloid as spermicidal agents. Other compound such as tannins had effect in semen coagulation and flavonoid glycoside has antihyaluronidase activity

The evaluation of the fertility recovery has been reported by Orlu and Ogbalu (2012) which stated that 35 days after cessation of treatment, the animals in the recovery group regained fertility and produced litter. The ability of the treated rats to recover is indication of the possibility that anti-spermatogenic and inhibitory effect of the extract is reversible and the treated rat regained fertility after one full cycle of spermatogenesis. It was concluded that the inhibitory effect and anti-spermatogenic like spermicidal and hepatotoxic effects may be reversible within 35 days after the cessation of treatment in mice. Another report came from Faridha et al. (2006) and Lohiya et al. (1999) who reported fertility recovery in mice 70 days after exposure to aflatoxin $\mathrm{B}_{1}$ for 45 days and fertility recovery in rabbits treated with chloroform extract of Carica papaya seed, respectively.

Observations of the spermatogenesis degrees in this study can predict the sperm quality produced. It was assumed that the spermatogenesis degree would be in line with the sperm quality.

\section{Sperm Quality}

Sperm quality (motility, concentration and abnormality) of male rats that were administered with pegagan extract and experienced cessation of administration (recovery period) is presented in Table 3, 4 and 5.

The results showed that sperm motility of treated rats after pegagan administration ranged from 53.33 to $70.00 \%$, while in control rats the sperm motility ranged between $70 \%$ and $80 \%$ (Table 3). Sperm motility of treated rats increased after 12 days cessation of pegagan, while in control rats, the sperm motility was the stable. Results showed that there was no interaction between dose-administration duration with cessation length treatments. There was no significant difference $(\mathrm{P}>0.05)$ between treatments of dose-administration duration of pegagan on sperm motility. Similarly, treatments of cessation length did not significantly affect sperm motility, although these results indicated that cessation of pegagan extract for 12 days increased sperm motility.

Mechanism of action of pegagan extract to decrease sperm motility is unknown, but some researchers reported that sperm immobility caused by the content of compounds in plants can be either cell death (Lohiya et al., 2008), damage to the cell membrane (Chakrabarti et al., 2003), decreased ATP and chromatin damage (Hikim et al., 2000). Furthermore, it may through spermicidal effect from triterpen, flavonoid and

Table 3. Sperm Motility of Rats after Pegagan Extract Administration and Cessation of Pegagan Extract

\begin{tabular}{cccc}
\hline $\begin{array}{c}\text { Treatment of Dose- } \\
\text { administration Duration of } \\
\text { Pegagan Extract }\end{array}$ & $\begin{array}{c}\text { Sperm Motility (\%) after Cessation of Pegagan } \\
\text { Extract for }\end{array}$ & \multirow{2}{*}{ Means } \\
\cline { 2 - 3 } & 1 day & 12 days & \\
\hline $450 \mathrm{mg}-21$ days & $53.33 \pm 20.82$ & $66.67 \pm 5.77$ & $60.00 \pm 15.49$ \\
$600 \mathrm{mg}-21$ days & $56.67 \pm 5.77$ & $63.33 \pm 5.77$ & $60.00 \pm 6.32$ \\
$450 \mathrm{mg}-28$ days & $56.67 \pm 23.09$ & $46.67 \pm 11.55$ & $51.67 \pm 17.22$ \\
$600 \mathrm{mg}-28$ days & $60.00 \pm 0.00$ & $70.00 \pm 0.00$ & $65.00 \pm 5.48$ \\
Means & $56.67 \pm 13.71$ & $61.67 \pm 11.15$ & \\
\hline
\end{tabular}

Result were not significant $(\mathrm{P}>0.05)$ 
Table 4. Sperm Concentration on Rats after Administration and Cessation of Pegagan

\begin{tabular}{ccc}
\hline $\begin{array}{c}\text { Treatment of Dose- } \\
\text { administration Duration of } \\
\text { Pegagan Extract }\end{array}$ & \multicolumn{2}{c}{$\begin{array}{c}\text { Sperm Concentration (million cells } / \mathrm{mL} \text { ) after Cessation of Pegagan } \\
\text { Extract for }\end{array}$} \\
\cline { 2 - 3 } & 1 day & 12 days \\
\hline $450 \mathrm{mg}-21$ days & $475.00 \pm 66.14^{\mathrm{ab}}$ & $475.00 \pm 125.00^{\mathrm{a}}$ \\
$600 \mathrm{mg}-21$ days & $366.67 \pm 52.04^{\mathrm{a}}$ & $541.67 \pm 38.19^{\mathrm{a}}$ \\
$450 \mathrm{mg}-28$ days & $508.33 \pm 38.19^{\mathrm{b}}$ & $425.00 \pm 50.00^{\mathrm{a}}$ \\
$600 \mathrm{mg}-28$ days & $416.67 \pm 52.04^{\mathrm{ab}}$ & $500.00 \pm 108.97^{\mathrm{a}}$ \\
\hline
\end{tabular}

The numbers in the same column followed by the different letter are significantly different at $5 \%$ level of Duncan test

Table 5. Sperm Abnormality on Rats after Administration and Cessation of Pegagan Extract

\begin{tabular}{cccc}
\hline $\begin{array}{c}\text { Treatment of Dose- } \\
\text { administration Duration of } \\
\text { Pegagan Extraction }\end{array}$ & $\begin{array}{c}\text { Sperm Abnormality (\%) after Cessation of } \\
\text { Pegagan Extract for }\end{array}$ & Means \\
\cline { 2 - 3 } & 1 day & 12 days & \\
\hline $450 \mathrm{mg}-21$ days & $4.33 \pm 2.13$ & $1.83 \pm 1.28$ & $3.08 \pm 2.08$ \\
$600 \mathrm{mg}-21$ days & $2.17 \pm 1.26$ & $2.25 \pm 1.56$ & $2.21 \pm 1.27$ \\
$450 \mathrm{mg}-28$ days & $2.75 \pm 1.32$ & $4.42 \pm 2.67$ & $3.58 \pm 2.09$ \\
$600 \mathrm{mg}-28$ days & $1.25 \pm 0.66$ & $2.92 \pm 1.88$ & $2.08 \pm 1.55$ \\
Means & $2.63 \pm 1.70$ & $2.85 \pm 1.93$ & \\
\hline
\end{tabular}

alkaloid; a denaturing effect on one or more proteins involved in semen coagulation from tannins or anti-hyaluronidase activity from flavonoid glycoside (Farnsworth and Waller 1982; Joshi et al., 2011). Sperm concentration after administration and cessation of pegagan is presented in Table 4.

Sperm concentration increased after 12 days cessation of pegagan extract, except in $450 \mathrm{mg}-28$ days treatment. The anova result showed that there was interaction between dose-administration duration with cessation length treatments. On 1 day cessation of pegagan extract, treatment doseadministration duration significantly affected sperm concentration, while the highest concentration happened in the $450 \mathrm{mg}$ - 28 days treatment followed by $450 \mathrm{mg}-21$ days, $600 \mathrm{mg}$ 28 days and $600 \mathrm{mg}-21$ days treatments, respectively. Treatment $600 \mathrm{mg}-21$ days was significantly different from treatment $450 \mathrm{mg}-28$ days, but not significantly different from other treatments. Sperm concentration increased after
12 days cessation of pegagan extract for treatments $600 \mathrm{mg}-21$ days and $600 \mathrm{mg}-28$ days. Control rats in this study showed higher sperm concentration than treated rats (541.67-600.00 million cells $/ \mathrm{mL}$ ) which indicated that sperm concentration in treated rats decreased after administration and cessation of pegagan extract when compared with control, although treated rats still maintained normal sperm count.

Active compounds contained in pegagan extract possibly caused damage to the Sertoli cells, which are directly involved in the production of spermatozoa and spermatogenesis continuity. The damage of the cell will lead to inhibition of spermatogenesis. Okamura et al. (2004) stated that Sertoli cells play a critical role in spermatogenesis by providing physical support, nutrients and hormonal signals necessary for successful spermatogenesis. According to Gupta et al. (2006), decline in sperm counts was related to direct damage of the Leydig cells and Sertoli cells that are directly involved in sperm 
production. Sperm abnormality after administration and cessation of pegagan extract is showed in Table 5.

There was no interaction between treatments of dose-admininstration duration with cessation length. There was no significant difference between treatments of dose-administration duration of pegagan extract on sperm abnormality. Similarly, treatment of cessation length of pegagan extract did not significantly affect sperm abnormality. This result also showed that sperm abnormalities remained within normal values $(<30 \%)$. These results indicated that pegagan extract did not affect sperm abnormality, especially on sperm with circular tail and head sperm without tail. Abnormality of spermatozoa in healthy mice was $\leq 30 \%$ (Johnson and Barry 1998).

\section{Testosterone Level}

Testosterone levels after administration and cessation of pegagan extract are presented in Table 6. Results showed an increase in testosterone levels after 12 days of cessation of pegagan extract in treated rats with $450 \mathrm{mg}-21$ days and $600 \mathrm{mg}-21$ days treatments, but there was no testoterone level increase in treated rats with $450 \mathrm{mg}-28$ days treatment. Results of analysis showed that there was no interaction between treatments of dose-administration duration with cessation length. There was no significant difference between treatments of doseadministration duration of pegagan extract on testosterone levels. Similarly, treatment of cessation length did not significantly affect testosterone levels.

The decrease of testosterone level in treated rats with $450 \mathrm{mg}-28$ days treatment might be due to the damage in seminiferous tubules and Leydig cells of interstitial cells where testosterone is synthesized. This research also found that testosterone levels of control rats being force-fed for 21 and 28 days ranged from 1.03 to 1.63 and from 0.86 to $2.89 \mathrm{ng} / \mathrm{mL}$, respectively. When compared with control rats, the results of testosterone levels from this study showed that the levels of testosterone produced after pegagan extract administration with 12 days cessation was in the normal range. This suggested that the pegagan extract administration was still able to maintain testosterone levels in the normal range. It was thought that pegagan had no effect on the hypothalamus-hypophysis-testis pathway, but tended to directly influence the occurrence of testicular damage in some seminiferous tubules and interstitial cells.

According to Walker (2011) there are several pathways of how testosterone plays a role in spermatogenesis, i.e. the classical pathway and non-classical pathway. In the classical pathway, testosteron diffuses through the plasma membrane and binds Androgen Receptor (AR). Change in AR conformatioal cause the receptor to be released from heat shock protein and translocate to the nucleus where it binds to Androgen Response Elements (AREs), recruits co-regulator proteins and regulates gene transcription. In nonclassical pathway there are at least two mechanisms of testosterone action in Sertoli cells : 1) Ca influx pathway, testosteron rapidly induces the influx of $\left[\mathrm{Ca}^{2+}\right]$ into Sertoli cells through L-Type channels; 2) activation of Src, EGFR, kinase and CREB.

Testosterone supports spermatocyt

Table 6. Testosterone Level on Rats after Administration and Cessation of Pegagan Extract

\begin{tabular}{cccc}
\hline $\begin{array}{c}\text { Treatment of Dose- } \\
\text { administration Duration } \\
\text { of Pegagan Extract }\end{array}$ & $\begin{array}{c}\text { Testosterone Level (ng/mL) after Cessation of } \\
\text { Pegagan Extract for }\end{array}$ & Means \\
\cline { 2 - 3 } & 1 day & 12 days & \\
\hline $450 \mathrm{mg}-21$ days & $1.05 \pm 0.24$ & $3.82 \pm 3.96$ & $2.46 \pm 2.42^{\mathrm{a}}$ \\
$600 \mathrm{mg}-21$ days & $1.04 \pm 0.42$ & $1.66 \pm 0.47$ & $1.76 \pm 1.10^{\mathrm{a}}$ \\
$450 \mathrm{mg}-28$ days & $2.82 \pm 0.57$ & $1.68 \pm 0.26$ & $2.31 \pm 0.89^{\mathrm{a}}$ \\
$600 \mathrm{mg}-28$ days & $3.19 \pm 1.64$ & $3.15 \pm 1.92$ & $2.84 \pm 1.47^{\mathrm{a}}$ \\
Means & $2.02 \pm 1.28^{\mathrm{a}}$ & $2.58 \pm 2.13^{\mathrm{a}}$ & \\
\hline
\end{tabular}

Result were not significant $(\mathrm{P}>0.05)$ 
maturation, especially (at least in rat) in development of round spermatid to be elongated spermatid (Ruwanpura et al., 2010). Testosterone is required for germ cells to progress beyond meiosis and testosterone is required for the release of mature spermatids during stage VIII in rats (Sharpe, 1994).

Results of this study showed that pegagan extract administration did not decrease testosterone levels to under normal levels which indicated that the pegagan extract administration did not decrease male rat's libido. This finding suggests that pegagan can be used as male contraceptive because it will not affect male's libido or sexual function.

The mechanism of improvement in degree of spermatogenesis, sperm quality and testosterone levels after 12 days cessation of pegagan extract in treated rats with $450 \mathrm{mg}-21$ days and $600 \mathrm{mg}$ 21 days treatments can not be explained from the results of this study because it did not occur in treated rats with $450 \mathrm{mg}-28$ days and $600 \mathrm{mg}-28$ days treatments. It was thought to be caused by several factors such as individual factor to response the influence of pegagan or perhaps because of the recovery of testicular that support androgenesis. If there is the recovery of the testicle, it is suggested that the effects of pegagan is reversible, so the damage can be recovered if the administration is stopped.

Based on these results, it showed that pegagan extract administration up to $600 \mathrm{mg} / \mathrm{kg}$ for 28 days would decrease the degree of spermatogenesis, sperm quality and testosterone levels within the normal range and the decrease would be reversible. However, treated rats with $450 \mathrm{mg}-28$ days treatment experienced damage to the testicles that affected the quality of sperm, although there was no effect on testosterone levels. Therefore, dose and administration duration have to be considered when using pegagan. These results showed that pegagan extract administration had no effect on testosterone level. The results of this study suggested that there would be no decreased libido and no permanent testicles damage. Therefore, pegagan can be developed into a safe and effective male contraceptive. Some constraints to male contraceptive development include inhibition of sperm production which interfere with the function and maturation of the sperm and inhibiting sperm transport (Wu 1996; Thakur et al. 2010). To understand more about pegagan effect on fertility, it is suggested to conduct further research to investigate the fertility after administration and cessation of pegagan extract which can be done by mating the male rat with estrous females.

\section{CONCLUSION}

Administration of pegagan extract reduce degress of spermatogenesis, semen quality and testosteron level in rats, but this effect was reversible after cessation of pegagan administration for 12 days. Pegagan extract has potency as antifertility agent and dose of 600 $\mathrm{mg} / \mathrm{kg} \mathrm{BW}$ of pegagan extract for 21 or 28 days may be concidered as antifertility agent on rats.

\section{ACKNOWLEDGMENTS}

This research was supported by Ph.D Student Research Grant from SEAMEO BIOTROP, Jl. Raya Tajur KM 6, Bogor, West Java-Indonesia.

\section{REFERENCES}

Chakrabarti, K., S. Pal and A.K. Bhattacharyya. 2003. Sperm immobilization activity of Allium sativum L. and other plant extracts. Asian J. Androl. 59(2):131-135.

Faridha, A., K. Faisal, and M.A. Akbarsha. 2006. Duration-dependent histopathological and histometric changes in the testis of aflatoxin B1-treated mice. J. Endocrinol. Reprod 10(2): $117-133$

Farnsworth, N.R. and D.P. Waller. 1982. Current status of plant products reported to inhibit sperm. . Edited by Zatuchni GI. Northwestern University, Evanston. Res. Front Fertil. Regul. 2(1): 1-16.

Gupta, R.S., M. Kanwari, H. Rehwani, S.K. Verma and M.P. Dobhal. 2006. Contraceptive Efficacy of Strychnos potatorum Seed Extract in Male Albino Rats. Asian J. Exp. Sci. 20(1): 181-187.

Heidari, M, A.H. Jamshedi, S.H. Akhondzadeh, M. Ghaffari, M.R. Sadeghi and M.G. Khansari. 2007. Evaluating the effects of Centella asiatica on spermatogenesis in rats. $\mathrm{J}$ Reprod. Infertil. 7(4):367-374.

Heidari, M, H. Heidari-Vala, M.R. Sadeghi and M.M Akhondi. 2012. The inductive effects of Centella asiatica on rat spermatogenic cell apoptosis in vivo. J. Nat. Med. 66:271-278

Hikim, A.P., Y.H. Lue, C. Wang, V. Reutrakul, R. 
Sangsuwan and R.S. Swerdloff. 2000. Posttesticular antifertility action of triptolide in the male rat: evidence for severe impairment of cauda epididymal sperm ultrastructure. J. Androl. 21(3):431-437.

Johnson, M.H. and J.E. Barry. 1998. Essential Reproduction. London (GB): Blackwell Science Ltd.

Joshi, S.C.. A. Sharma and M. Chaturvedi. 2011. Antifertility potential of some medicinal plants in males: An Overview. Int. J. Pharmacy Pharm. Sci. 3(5): 204-217.

Kiernan, J.A.1990. Histological and Histochemical Methods: Theory and Practice $2^{\text {nd }}$ ed. New York (US): Pergamon Press.

Lohiya, N.K., N. Pathak and P.K. Mistra, B. Maniovannan.1999 .Reversible contraception with chloroform extract of Carica papaya Linn: Seeds in male rabbits. Reprod. Toxicol 13(1): 59-66.

Lohiya, N.K, B. Manivannan, S. Goyal and A.S. Ansari. 2008. Sperm motility inhibitory effect of the benzene chromatographic fraction of the chloroform extract of the seeds of Carica papaya in langur monkey, Presbytis entellus entellus. Asian J. Androl. 10(2): 298-306.

Noor, M.M. and N.M. Ali. 2004. In vivo effects of Centella asiatica leaf extract on the histology of testis and sperm quality in mice. Sains Malay. 33(2):97-103.

Okamura, M, T. Watanabe, Y. Kashida, N. Machida and K. Mitsumori. 2004. Possible mechanisms underlying the testicular toxicity of oxfendazole in rats. Toxicol. Pathol. 32(1):1- 8 .

Orlu, E.E and O.K. Ogbalu. 2012. Litter size, sex ratio and some liver biomarkers in sprague- dawley rats recovering from exposure to ethanol extract of Lepidagathis alopecuroide. J. Biol. Sci. 4(5):643-648.

Ruwanpura, S.M., R.I. McLachlan and S.J. Meachem. 2010. Hormonal regulation of male germ cell development. J. Endocrynol. 205: 117-131.

Sharpe, R.M. 1994. Regulation of spermatogenesis. In: Knobil E, Neil JD, editor. The Physiology of Reproduction. New York(US): Raven Press.

Solihati, N, B. Purwantara, I. Supriatna and A. Winarto. 2013. Perkembangan sel-sel spermatogenik dan kualitas sperma pascapemberian ekstrak pegagan (Centella asiatica) extract. J. Ilmu Ternak Vet. 18(3):192-201.

Syahrum, M.H. 1997. Biopsi testis sebagai pengevaluasi pasien zoospermia. Majalah Kedokteran Indonesia. 47(5):232-236.

Thakur, D.S, P. Kumar, A. Kujur and P. Kumar. 2010. Contribution of male contraception in world population. J. Pharm. Sci. Res. 2(7): 384-393.

Walker, W. H. 2011. Testosterone signaling and the regulation of spermatogenesis. Landes Biosci. 1(2):116-20.

Wu, F.C.W.1996. Male contraception. Bailliere's Clin. Obs. Gyn. 10(1):1-23.

Yunianto, I., S. Das and M.M. Noor. 2010. Antispermatogenic and antifertility effect of pegaga (Centella asiatica $\mathrm{L}$ ) on the testis of male Sprague-Dawley rats. Clin. Ter. 161(3): 235-239.

Zheng, C. and L. Qin. 2007. Chemical components of Centella asiatica and their bioactivities. J Chinese Integ. Med. 5(3):348351. 